\title{
Politics of Memory in Cities Divided by State Borders: Theoretical and Methodological Framework of Research ${ }^{*}$
}

\author{
Polityki pamięci w miastach podzielonych granicą państwową. \\ Teoretyczne i metodologiczne ramy badań
}

\section{- Abstract •}

In the article the author attempts to outline theoretical and methodological framework used in analyzing the phenomenon of specific history politics in cities divided by state borders - places where sometimes radically different history narrations meet or even clash. The article is composed of three parts. The first one specifies the concept of history politics in nationwide dimension ("history politics"). The second part analyzes history politics in local dimension ("local politics of memory"). With reference to these two concepts - levels of history politics and politics of memory - the author indicates: goals, subjects, methods and tools of history politics/ politics of memory. The final section of the paper aims at capturing the specificity of history politics in cities divided by state borders and in-

\section{- Abstrakt •}

W artykule autor podejmuje próbę zarysowania teoretycznych i metodologicznych ram służących badaniu zjawiska poszczególnych polityk pamięci w miastach podzielonych granicami państwowymi, które stanowią miejsce spotkania lub zderzenia często radykalnie odmiennych narracji historycznych. Artykuł składa się z trzech części. Część pierwsza służy doprecyzowaniu pojęcia polityki historycznej w wymiarze ogólnonarodowym („polityka historyczna”). W części drugiej przedmiotem analiz jest polityka historyczna w wymiarze lokalnym („lokalna polityka pamięci”). W odniesieniu do obydwu pojęć - poziomów polityki historycznej/pamięci - wskazano na: cele, podmioty, metody i narzędzia polityki historycznej/pamięci. W trzeciej części artykułu podjęto próbę uchwycenia spe-

* The text was previously published in Polish: Zenderowski, R. (2021). Polityki pamięci w miastach podzielonych granicą państwową. Teoretyczne i metodologiczne ramy badań. In: R. Zenderowski (Ed.), Lokalne polityki pamięci w mieście podzielonym granica państwową. Cieszyn - Těsín Teschen (pp. 11-30). Warszawa-Cieszyn: Instytut Nauk o Polityce i Administracji Uniwersytetu Kardynała Stefana Wyszyńskiego w Warszawie. 
dicating models of relations between different kinds of politics of memory in cities divided by state borders.

Keywords: cities divided by state borders; history politics; politics of memory; collective memory cyfiki polityki pamięci w miastach podzielonych granicą państwową i wskazania na modele relacji występujących między politykami pamięci w miastach podzielonych granicą państwową.

Słowa kluczowe: miasta podzielone granicą państwową; polityka historyczna; polityka pamięci; pamięć zbiorowa

\section{Introduction}

The aim of this article is to specify the research area, define theoretical framework and indicate potential vectors of research exploration. At the heart of theoretical considerations is politics, or, to be more precise, different policies dealing with "building" or "generating" collective memory (material scope) in local dimension, but with a very strong supra-local/international component, since the subject of our analysis are cities divided by state borders ${ }^{1}$ (spatial scope) and various types of "memory producers" (subject scope). Time scope is not specified as the article does not refer to specific cases of divided cities, its ambition being to develop theoretical-methodological framework for case studies and comparative analyses.

The observation of, on the one hand, such memory artifacts as: monuments, sculptures, commemorative plaques or names of streets, squares or greens, and on the other hand - ceremonial celebrations of various anniversaries, demonstrations, proclamations, etc., in divided cities of Central and Eastern Europe (especially in: Cieszyn-Český Těšín, Komárom-Komárno, Sátoraljaújhely-Slovenské Nové Mesto, Kosovska Mitrovica-Mitrovicë2), led me to put forward a hypothesis that in such places local policies of memory are often in strong opposition to each other and become a place of particular accumulation and confrontation of nationwide

${ }^{1}$ Cities located on both sides of a state border, touching each other spatially, are usually given the following terms in international literature of the subject: divided cities, duplicated cities, connected cities; less popular terms include: double cities, bi-national cities, trans-border cities, border-crossing cities, mother-daughter cities, international border cities, partitioned border cities, split-up cities. On the other hand, such concepts as neighbor cities or companion cities generally refer to cities which do not touch spatially, but are located very close to each other. A specific category is formed by gateway cities - located on the border or in its vicinity, performing various functions connected with handling border movement (Buursink, 2001, p. 15; Schultz, Stokłosa, \& Jajeśniak-Quast, 2002, p. 3; Joenniemi \& Sergunin, 2009, pp. 16-21; Harvey, 2012, pp. 380-384; Burghardt, 1971, p. 269).

2 An example of the border separating the Serbian and Albanian parts of a city in Kosovo, not recognized by a significant part of international community. Thus the border dividing the city does not have the status of a state border. 
resentment, feeling of injustice on the one hand, and ostentatiously demonstrated national pride on the other hand. Local collective memory is closely intertwined in these cases with national collective memory "produced" by adopting nationwide or statewide history politics.

The article is of theoretical nature and does not refer to case studies, which the author intends to present in a separate article or a series of papers devoted to selected cases of cities divided by state borders and politics of memory implemented in them. It consists of three parts. The first one specifies the concept of history politics in nationwide dimension (here I use the term "history politics"). The second part brings an analysis of history politics in its local dimension ("local politics of memory"). In both cases, I decided to define key aspects of the examined phenomenon, especially: goal, subjects, methods and tools of history politics/politics of memory. I use the concept of "politics" to denote intentional and organized activity aimed at accomplishing particular goals that are important to a given community and at legitimizing specific political authority or a group aimed at holding authority. The last part of the article attempts to capture the specificity of politics of memory in cities divided by state borders and to indicate models of relations between different kinds of politics of memory in cities divided by state borders.

In the last part of the paper, I rely on experiences connected with participant and non-participant observations of places and events that have taken place or are still happening in the already-mentioned divided cities. I found two methods, namely: (a) content analysis, and (b) comparative analysis, particularly useful in accomplishing my research goal. Content analysis consists in analyzing both documents and broadly understood communication artifacts. It allows us to reduce the content of the whole text to its most important meanings: most frequently used words, key topics, dominant grammatical and semantic forms. Its goal is thus to capture certain communication tendencies. The subject of analysis is, first of all, identifying what names of public places, monuments and commemorative plaques communicate, and secondly, what is being said about these places and their significance for local community. Comparative analysis allows us, in this case, to compare particular politics of memory in the aspect of its content in form of communication messages (events) concerning their essence, category, genre, or form.

\section{History Politics: An Outline of the Concept}

Though the concept of history politics appeared quite recently in social science (German Geschichtspolitik is its precursor), numerous papers have been devoted to 
definition analyses, aimed at capturing the essence and the subject scope of history politics, as well as developing a typology of history politics, trying to indicate various models of history politics. Moreover, in recent years we have seen a number of case studies devoted to selected types of history politics on central and local (regional) levels.

Keen interest in collective memory began in the 1970s, when it was no longer treated as an individual's trait, but a social rather than individual capability (Chwedoruk, 2018, p. 255). History politics, sometimes called politics of memo$\mathrm{ry}^{3}$, since its very beginning, in the 1980s, when the concept appeared in scientific literature ${ }^{4}$ (history politics was used at least since the Enlightenment period), has been in the field of interest of political scientists and historians as well as sociologists, philosophers and anthropologists.

However, the relationship between politics and history was the subject of scientific reflection much earlier. "The question about the nature and limits of mutual merging of politics and history appeared briefly as a subject of reflection in modern history science in a text by German historian, Leopold Ranke, Über die Verwandtschaft und den Unterschied der Historie und der Politik (1836) - as Anna Wolff-Powęska observes (2007, p. 7). The works of Bronisław Trentowski, who used the concepts of "political historicism" and "history politics", come from the same period (Chwedoruk, 2018, pp. 125-126).

It should also be noted that whereas the concept and systematic theoretical reflection on the phenomenon of history politics are only a few decades old, politics of history itself (understood in categories of political action) or various ties between politics and history date back to ancient times. "Even in distant eras of humankind, community governance consisted in taking political actions, in which remembered information was implicitly or explicitly evoked as well as mythologized opinions about the past. They were used in order to accomplish set goals" (Ponczek, 2013, p. 10). E. Ponczek claims that it was specific history pre-politics, "of which past po-

3 Political scientists prefer the term "history politics" (its linguistic precursor is German Geschichtspolitik), whereas "politics of memory" (originating in the Anglo-Saxon culture) is favored by sociologists (Kącka, 2015a, pp. 63-64). In addition to these two concepts, the term "politics of historical memory" is used (Malczewska-Pawelec \& Pawelec, 2011, p. 18).

${ }^{4}$ It is assumed that the term gained popularity in the 1980s and was first used in the scientific forum by a historian specializing in ancient times, Christian Meier, during the convention of German historians in Trier in 1986 (Kącka, 2015a, p. 63; see: Meier, 1987). However, several years earlier, H. Zinn published a book, which did not arouse such significant interest in history politics (see: Zinn, 1970). According to R. Chwedoruk, the concept of 'history politics' was intentionally used and scientifically conceptualized in Germany. Later on, according to the author, Poland joined the group of precursors of modern politics of history and then - Russia (Chwedoruk, 2018, p. 139). 
litical decision-makers were not aware, although they might have observed that reference to particular tradition justifies and legitimizes the execution of authority in the state" (Ponczek, 2013, p. 11).

In political science, history politics is perceived in principle $^{5}$ as one of specific policies of the state. And it enjoys special status, since, as observed by J. Chrobaczyński, "nobody speaks of 'physical politics', 'biological politics', 'mathematical politics', and yet thousands insist that there is something they call 'history politics"' (Chrobaczyński, 2018, p. 99). Thus, it must be assumed that the state is the subject (creator) of history politics, or, to be more precise, its specialized organs, which initiate cooperation with non-state entities ${ }^{6}$. Just like a number of specific policies, history politics is closely related to other policies (specific or sector ones) of the state, such as: education policy, scientific research policy, ethnic policy, religious policy, cultural policy, media policy, regional policy and last but not least - foreign policy. History politics is present both in the internal politics dimension and in foreign politics of the state. It seems to be one of the youngest specific policies, accomplishing its goals "in cooperation" with other abovementioned policies of the state. Therefore, many authors are of an opinion that history politics may be analyzed either as autonomous specific policy (remaining, however, in defined relations with other specific policies), or as a "component" of other specific policies (Ponczek, 2013, p. 10). In this sense, each time we deal with intentional actions of state organs or entities commissioned by them. It should be emphasized, since some authors also include in history politics "all activities - conscious and unconscious, intentional and accidental - which lead to consolidation and strengthening of collective memory [...] or its change" (Nijakowski, 2008, p. 43).

It is assumed that the fundamental and superior goal of history politics of a state is to ensure integrity of the state and the nation (understood more narrowly: in ethno-cultural categories, or more broadly: in political categories) and functionality of a particular political regime in power (ad intra activities), as well as

5 We may wonder whether entities conducting history politics may include non-state nations (for example, deprived of their own state). Wasn't Polish history politics most effective in the period of the Partitions, when the Polish state did not exist? If we provided a positive answer to this question, we would have to verify the list of goals and methods of history politics. In this text, while avoiding to deny the claim that history politics may be the work of non-state nations, I state that in principle the entity conducting such politics is a state or, more widely, state-building elite.

6 Reinhart Koselleck presents the pluralism of history politics actors in the 7 x P formula: professors, politicians, priests, pedagogues, poets, publishers, PR officers (Koselleck, 2006, pp. 13-24, quoted after: Chwedoruk, 2018, p. 191). 
to build the power of the state (in hard power and soft power dimensions) in international relations (ad extra activities).

The accomplishment of history politics goals in the first of the above-mentioned dimensions (ad intra) is particularly important in situations of deep political divisions and ideological tension inside a particular society. The aim of history politics is then to strengthen "the common denominator" in the area of attitudes, norms and values growing from historical heritage of a particular nation. The aim of this politics affirming a certain catalogue of values is to support continuity between generations through inter-generational "transfer of collective memory" (positive approach). "Collective historical memory constitutes one of fundamental indicators of identity for the community carrying it as well as an important factor in integration of such community in the area of values and ideas. The contents circulating in collective memory determine attitudes of community members and the shape of actions taken by them towards each other and towards members of other groups (and towards other groups as a whole). They also affect the system of norms prevailing in a given community. What is particularly important, in contemporary mass societies historical memory appears to be an important tool of rule and social control" (Malczewska-Pawelec \& Pawelec, 2011, p. 17). It must be remembered that "the process of rebuilding memory does not take place in intellectual vacuum. Its context is most of all determined by the current historical memory, the result of previous experiences of community, including also the effects of politics of memory conducted so far" (Malczewska-Pawelec \& Pawelec, 2011, p. 30).

National community can be reinforced through affirmation of commonly shared values, simultaneously and parallel to creation of a negative image of another country or nation, presented on the scale: other - stranger - rival - enemy, and specific events connected with it (negative approach). Referring to this aspect of history politics, J. Olędzka notices that "visions of history politics naturally build an area of confrontation, but do not automatically imply conflicts. On the contrary, their processuality offers an opportunity (in a short-time or long-time perspective) of dialogue between groups, nations, societies, states, and this action does not contradict the accomplishment of national interest of particular states. What generates conflicts, though, is the instrumental treatment of politics of memory, introducing falsified historical arguments to public debate (also in international dimension), which not only treat history selectively, but also manipulate it according to immediate needs. Then conflicts over memory may cause disputes in supranational dimension, antagonize nations, ethnic (including diaspora) and confession groups" (Olędzka, 2017, pp. 339-340). 
History politics usually uses alternating affirmative rhetoric of glory and memory of "Golden Age" and outstanding achievements of (representatives of) the nation and, on the other hand, victimizing rhetoric of trauma and sacrifice (Zenderowski, 2009, pp. 65-93). Daniel B. MacDonald poses a very interesting and, in my opinion, justified thesis that since the Holocaust, the icon of Golden Age has lost its leading position in constructing national identities (MacDonald, 2005 , p. 99). It was replaced by an icon of national hecatomb, something that Dubravka Ugrešić aptly, though maybe too bluntly, describes as "pornography of disaster" (Ugrešić, 2006, p. 269). History politics, emphasizing the suffered harm, very often supports repossession and reparation efforts. History politics tools may also allow discrimination of all social groups, states and even nations (Kącka, 2015b, p. 50). A peculiar case is a rhetoric of guilt and remorse for harm caused to other nations, an example of which is history politics of Germany after the Second World War, although elements of settling accounts with disgraceful past can be found in other history policies, though admittedly, they never dominate the narration. It is worth mentioning that attempts at critical reflection over own history and historical memory, leaving aside their content, rightness and intentions (not always noble ones), usually encounter applause of a part of elites and society, but also accusations of harming interests of one's country (for example, accusations of conducting the so-called "shame pedagogy").

A strategy offering an alternative to commemoration is policy of forgetting and erasing from collective memory those characters, events and institutions which are considered inadequate to the current political goals and image of the state or which are too antagonizing for particular society. In the paper titled "Five Strategies of Repression", Aleida Assmann distinguishes such strategies as: compensation, externalization, exclusion, silence, and distortion (Assmann, 2009, pp. 333-348).

Politicians have a lot of tools used for building and maintaining memory, ranging from the lyrics of the national anthem, the national emblem, names of public places (streets, squares, public utility buildings, etc.), symbolic images of places, people and events placed on coins and banknotes, monuments and commemorative plaques (both by erecting them and pulling them down), onomastics of urban space, through an official catalogue of national holidays, "medal policy", educational (school) programs, Internet portals and sites, cinematography, to building and developing "institutional infrastructure of politics of memory" in shape of museums and memorial places, aimed at promoting a particular version of history or intentionally leaving ruins of cities and districts or concentration camps as "witnesses of history", strongly appealing to our imagination (Woźniak \& Napora, 
2018, pp. 216-217). In subject literature we can find the term "memory industry" describing systematic and programmed history politics (see: Rosenfeld, 2009).

In addition to this official history politics created by political and cultural elite, expressed in the above-mentioned ways, we often encounter grass-roots (nonstate) history politics, which is usually supported by political decision-makers as long as it is consistent with the officially decreed "politics of memory". It frequently becomes a specific element of popular (mass) culture. Images of great heroes (for example, the so-called cursed soldiers) appear on clothes, stickers put on car windows or coffee mugs. The so-called reenactment groups, reconstructing the most important events in the history of a particular nation, are becoming increasingly popular. And last but not least, church institutions (local Churches) are specific creators of history politics, especially in Central and Eastern Europe region, as for centuries they stored collective memory if a given nation lost its statehood.

History politics is usually conducted, as I have already mentioned, in two directions - ad intra and ad extra (Wójcik, 2016, pp. 441-445).

In the case of ad intra history politics, relevant communication and messages containing historical content are directed at inhabitants of a given state.

History politics in its ad extra variant aims at creating a vision of history for a foreign recipient that will arouse respect and that will effectively compete with rival narratives related to the history of a given state and nation, created by third countries. It should be noted that history politics "in its export version" is, by definition, significantly simplified and exaggerated as it cannot refer to even elementary knowledge of specific aspects of history possessed by a "statistical" foreign recipient. History politics consists then in imposing "narration in international space through unambiguous evaluation of collective images of the past, made by means of relationally evaluative concepts, such as: guilt, responsibility, sacrifice, or pride" (Barszcz \& Pilawa, 2018, p. 53).

The shape, content and ways of creating history politics are greatly affected by the system prevailing in a given state.

In liberal democracy countries, authorities usually try to take into consideration certain pluralism of views on significance of historic events, persons, institutions and related values. History politics of authoritarian and totalitarian states is based on radically different principles. Firstly, science and scientific research are closely subordinated to a particular regime because they are expected to provide legitimization for the ruling party (including the leader) and its politics, even if this can be achieved by means of "twisting" the results of scientific research (in this case, in historical sciences) to fit particular ideological assumptions. Secondly, generally pluralism of various historical narrations is not allowed, while the official version 
of history is imposed on the society, and its knowledge is often checked. Thirdly, a common feature of an overwhelming majority of non-democratic regimes is strong concentration of history politics on national enemy, which can be a particular nation, country or ideological system, usually represented by a certain country or group of countries (Kostro, 2009, pp. 7-8).

\section{The Specificity of Local Politics of Memory}

Local politics of memory should not be identified with nationwide history politics implemented on the local (city, regional) level. Local politics of memory constitutes "all intentional actions taken publicly, aimed at influencing the way the past of a given area, smaller than a state, is perceived by its inhabitants and people identifying themselves with it or staying in it (for example, for tourist purposes)" (Skoczylas, 2015, p. 251). These actions may be, and usually are, consistent with the assumptions of nationwide history politics. Such centers are usually very effective in imposing their narration: ideology, norms, values and even language, to representatives of local elite and force the operation of institutions corresponding to their standards (Wałdoch, 2017, p. 52). Łukasz Skoczylas observes that "periods in which local history politics becomes almost identical with its state version usually mark years of significant geopolitical changes or periods following them. The best example is the history of rebuilding large Polish cities after the Second World War" (Skoczylas, 2015, p. 250). It is rare, however, to observe a situation in which a particular region has politics of memory that would be openly confrontational to nationwide history politics. Such situations can be seen especially in regions with advanced separatist tendencies, sufficiently strong base in shape of political and cultural elite unfriendly or, in extreme cases, hostile to the center.

Between these two - essentially typical - presentations, i.e., (a) implementation of nationwide history politics assumptions on the local level, and (b) conducting politics of memory opposed to nationwide history politics, there are a number of "situations in between". First of all, local politics of memory may supplement, by introducing complementary narration, history politics conducted from the position of the center. In this case, it emphasizes the significance of specific local events, which nonetheless constitutes part of nationwide historical narration. In this situation, local politics of memory specifies and supplements nationwide history politics, simultaneously performing the role of its local justification and legitimization. Secondly, we can also imagine local politics of memory whose elements can be considered autonomous and not closely related to nationwide history politics, but at the 
same time, not in any obvious conflict with it. Here we stress, for example, significance of those positive historical experiences of inhabitants of a given region before it was incorporated into a particular national state.

Finally, it should be noticed that at the local level there are often a few different kinds of politics of memory, which emphasize the weight and importance of different traditions, people, events, customs, and values. The same historic events or persons may be even evaluated extremely differently by representatives of elite conducting particular local politics of memory. This sometimes leads to various social tensions, mutual aversion, disapproval, "ostentatious ignorance", or politics of "silencing" competitive narrations. In various periods of time, various kinds of local politics of memory gain greater significance, which is usually connected with the period of above-mentioned geopolitical turning points, transformations in nationwide history politics or long-term changes of norms and values professed in a given community (Wolff-Powęska, 2010).

In order to determine the specificity of local politics of memory and its relation to nationwide history politics, we should answer the following questions about: (a) the subjects of this politics, (b) its goals, (c) methods and tools.

Subjects of local politics of memory. While state authorities, creators of official history politics, have various specialized institutions (such as ministries of education, science, culture, national defense; parliament commissions, teacher training centers, etc.) at their disposal, local politics of memory is characterized by significant dispersion of "broadcasters" (narrators) of particular historical and memory content. Apart from local authorities, which differ in degree and intensity of conducting politics of memory, the key role is played by fans of regional history, involved in various forms of undertakings (often initiating them) aimed at popularizing particular knowledge and memory of historical events and heroes. Such people are often called "social memory leaders", "memory creators", "reflective elite", "local opinion leaders" (Skoczylas, 2015, p. 250; see also: Kansteiner, 2002, p. 180; WolffPowęska, 2007, p. 10; Nijakowski, 2006, p. 88). They are usually local politicians, journalists, teachers, scientists, people connected with art and culture, museum staff, librarians, priests, leaders of reenactment groups, etc. This circle of "memory creators" is quite wide and with diversified social and cultural background, opinions, and also representing different nationalities and religions. Therefore, it seems that at the local level we can observe certain pluralism of models of commemorating the past. When we have two or more kinds of local politics of memory, it is sometimes possible to indicate their centers, such as: associations and non-governmental organizations, public institutions (e.g., museums, libraries) or recently - In- 
ternet forums and communities promoting a specific vision of the past of a particular city or region. The latter differ from traditional centers of creating local politics of memory, as they are often characterized by anonymity of "memory creators", hiding under nicknames, believing that "it does not matter who says something, what matters is that it is said". To conclude the topic of subjects - creators of local politics of memory - we should observe that whereas in nationwide history politics the government plays the leading role in its creation, at the local level it is not necessarily the local politicians who determine the framework and directions of politics of memory. As Grzegorz Kęsik points out, "Polish politicians generally rarely use available instruments of shaping space intentionally, let alone historical space. They withdraw from this role, leaving it in hands of specialists - architects and urban planners, who are not ideologically indifferent to the matter they are to shape" (Kęsik, 2015, pp. 94-95).

Goals of local politics of memory. We can observe far-reaching convergence of the goals of nationwide and local history politics. Both cases consist in ensuring integrity and cohesion of a particular national or local community. Their goal is also to empower both communities in their relations with other communities, to give them some sort of "dignity traits" and pride of outstanding achievements in particular periods of history.

We must remember, however, that at the local level, two or more types of politics of memory might function simultaneously, and they might sometimes present opposite narrations. Then the goal is not necessarily to affect the whole local community, but only its part which is arbitrarily considered to be better and more rightly rooted in local topos, genos, ethos, or even logos (if ability to speak a local language or dialect is its indicator). Conducting specific politics of memory, its creators use the strategy of inclusion to/exclusion from the community, based on a specific catalogue of features and predispositions entitling individuals to be part of the community. In this way specific micro-nationalisms are created, aimed at shaping imagination and attitudes of members of a given community.

Analyzing strategies of inclusion and exclusion, we can easily observe two different tendencies among local "memory creators". The first one - which we can call "aristocratic" - aims at exclusivity, staying in a small, but outstanding (at least in their opinion) and exclusive circle (but attempting at widening its audience), whose goal is to take care of and preserve this part of local traditions which are believed to be the most valuable ones. But most of all, this strategy consists in counteracting external cultural influences which allegedly "dilute" local identity. This specifically understood conservatism may sometimes adopt forms of various obsessions 
and eccentricities, often leading to turning part of the local community into some sort of "open-air museum". The second tendency - which we can define as "democratic" one - aims exactly in the opposite direction. These creators of local politics of memory want to popularize among all inhabitants a specific memorizing narration which is generally flexible and in many aspects - unspecified, consisting more of slogans than content, and it sometimes looks infantile.

Methods and tools of local politics of memory. For obvious reasons, creators of local politics of memory do not have such a wide range of methods and tools as the state, which, for example, has the right to place relevant symbols on coins and banknotes or to conduct education policy. At present we can distinguish two parallel paths of "building memory" in the local dimension.

The first path - traditional one - is connected with commemorating particular persons or events by: naming public places (streets, squares, market squares, public utility buildings, etc.), erecting monuments or installing commemorative plaques. One can also mention here the dimension of spatial development policy whose goal is to conserve or transform (for example, erase some inconvenient historical traces) the historical space of a city. Other forms of building politics of memory seem less significant.

The second path of "building memory" is related to virtual space and development of the Internet and social media. It is thanks to them that many aficionados of local history could win public recognition and properly "expose" results of their historical search and analyses. On the Internet one can find, for example, virtual duchies, granting and taking away citizenship at the whim of self-anointed dukes. Local forums devoted to history of cities and regions are full of passionate substantive and non-substantive disputes. These are probably the most democratic, but also grotesque-prone forms of building and deconstructing collective memory.

\section{The Specificity of Politics of Memory in Cities Divided by State Borders}

The specificity of politics of memory in cities divided by state borders stems directly from the phenomenon of a city divided between various sovereign political entities which usually shape their identity and collective memory in a different way. It is in divided cities that different or even opposite narrations of the past meet. Here we must differentiate between two situations: (a) nationwide history politics conducted at the local level and directed by the political center to inhabitants 
of border peripheries, and (b) local (self-government, non-governmental) politics (or often different kinds of politics) of memory which remains the domain of the community living in the city or region. This differentiation is of vital importance especially to cities where the same ethnos dominates the population and symbolic sphere on both sides. This means that for one of the capital cities, the city in question, although its part is located within the administrative borders of the country, is an uncertain area, somehow strange, requiring increased propaganda efforts (for example, for Bratislava it is Komárno, Štúrovo ${ }^{7}$ or Slovenské Nové Mesto). In the analyzed case we can witness local politics of memory which may not be hostile to the official history politics of the country; nevertheless, it ignores its various postulates, treating it as not obligatory. This issue, which I only mention here, deserves a separate analysis devoted to relations between the center and borderlands in the process of shaping collective memory.

Local politics of history in a divided city, leaving aside the center-peripheries relations, is determined by a number of factors shaping its content. Referring to: (A) factors connected with the border as the essence of divided cities; (B) factors related to similarities and differences between both parts of the divided city, we can list a number of specific determinants of local politics of memory (Zenderowski \& Brzezińska, 2014, pp. 168-173).

(A) In the first group of factors one should mention: (a) the age of the border dividing the city (the older it is, the greater the probability of developing an autonomous - in terms of economy, infrastructure, society and culture - urban center and parallel communities) (Dębicki \& Tamáska, 2014, p. 6); (b) the existence of previous border experiences - here we can distinguish division into cities which were in close proximity to the state border before the division or even those which once were border cities, and cities with no border experience; (c) the status of the border - here an important criterion (especially if we analyze Europe) is membership in the European Union or the Schengen Area, as it has serious consequences for, inter alia, border permeability; (d) social attitude to the course of the border, expressed in considering it fair or unfair, often connected with (e) the way and circumstances in which the border was established (the border established as a result of bilateral negotiations or an arbitrary decision of superpowers).

(B) The second group of factors comprises: (a) the "height" of language barrier - determining everyday trans-border communication, facilitating or hinder-

${ }^{7}$ Formally Štúrovo, located opposite Hungarian city of Esztergom on the right bank of the Danube River, is not a divided city, but a twin one. 
ing close relations with neighbors across the border; (b) the existence of historical traumas connected with the neighbor nation and state - in the analyzed case we can often talk about collective memory in which the neighboring nation is "memorized" in categories of an aggressor or perpetrator of some injustice; one the one hand - it may be "fuelled" and used for current political games, and on the other - it may constitute only the "processed" element of memory of dramatic history, on the basis of which international reconciliation is being strived at; (c) ethnic structure of both parts of the city and existence of national and ethnic minorities in divided cities - here we can distinguish: $\left({ }^{*}\right)$ divided cities whose both parts are relatively ethnically homogenous, and this ethnic homogeneity may mean clear dominance of one nation on both sides of the divided city; $\left.{ }^{* *}\right)$ divided cities whose one part is ethnically relatively homogenous, whereas the other one is multi-ethnical, and part of the population may be made up of members of the neighbor nation or the community which is not part of the titular nation of one or the other side; $\left.{ }^{* * *}\right)$ divided cities whose both parts are ethnically heterogeneous; (d) percentage of indigenous and incoming population - this criterion distinguishes between: $\left(^{*}\right)$ cities with stabilized social structure, which did not experience significant "inflows" or "outflows" of population; $\left(^{* *}\right)$ cities in which social substratum has changed radically (this may refer to one or both parts of the divided city); (e) percentage of "trans-border families" - understood in two different ways: $\left({ }^{*}\right)$ ethnically homogenous families divided by the border; $\left({ }^{* *}\right)$ ethnically mixed families; (f) confession similarities and differences - here we can distinguish between: $\left(^{*}\right)$ divided cities whose both sides are dominated by the same confession; ${ }^{(*)}$ cities with two religiously differentiated parts; $\left.{ }^{(* *}\right)$ cities where one side is dominated by a specific religion while the other is dominated by another religion; it also happens that $\left(^{* * * *}\right)$ on one side of the city, regardless of its confession, population is significantly more religious than population inhabiting the other part of the divided city; (g) the level of socio-cultural development measured with "saturation" of socio-cultural institutions (universities, theaters, cinemas, libraries, etc.) here one can differentiate between: $\left(^{*}\right)$ divided cities in which both parts have similar potential allowing their social development; $\left(^{* *}\right)$ divided cities in which only one part has sufficient potential (institution base) allowing high level of social development, while the other part is a typical "dormitory town" - a city without any significant socio-cultural institutions.

Taking into consideration the above determinants and independent variables that potentially affect "intensity" and shape of specific politics of memory in divided cities, we can introduce several fundamental differentiations. Our starting point will be three model situations, in which: (a) local politics of memory is char- 
acterized by similar intensity in both cities; (b) it is hard to find any long-term and institutional activities connected with politics of memory in any of these cities; (c) on one side of the divided city we observe intense activities aimed at creating collective memory, while on the other side such efforts are hardly noticeable. In order to apply the intensity criteria, one must develop a proper scale, a set of defined values and objective measurement methods.

In the next step we could ask about autonomy of actions taken within local politics of memory. On the one hand, we can observe (a) situations in which a divided city is dominated by nationwide history politics, "applied" by entities not related to local authorities and directly or indirectly subordinated to central or regional authorities, which represent central authority in the region, on the other hand - (b) situations when we observe high level of autonomy of local politics of memory (especially in concrete actions and undertakings) from official history politics (which does not mean that such politics must oppose nationwide politics). This differentiation allows us to indicate three model situations: $\left(^{*}\right)$ divided cities in which official history politics, applied onto the local level, dominates on both sides; ${ }^{(* *}$ ) divided cities in which local politics of memory dominates on both sides; $\left({ }^{* *}\right)$ divided cities whose one side is dominated by official history politics transferred onto the local level, and the other side is dominated by local politics of memory (we leave aside situations when it is hard to indicate a specific type of politics).

Another important criterion is confrontational nature of politics of memory. It allows us to distinguish the following model situations: (a) politics of memory (regardless of the level at which it is formed - local or central) may be confrontational - particular historical events and processes, or characters in history of both nations may be interpreted generally divergently, in radically different ways, often with undisguised potential of hostility and aversion; (b) local politics of memory is generally not confrontational and demonstrates tendency to emphasize common positive historical experiences, but this is not accompanied by a process in which (c) local politics of memory shows a tendency to create a separate, trans-border world of common values, historical narrations, heroes and outstanding people valued by both communities of divided cities and regions.

\section{Conclusion}

The theoretical and methodological analysis conducted in this paper, especially in its final part, seems to be solid enough to create the framework for case studies devoted to politics of memory in selected cities divided by state borders as well as for 
comparative analyses of particular cities. So far scientists representing sociology, history, ethnology or cultural science have focused their analyses of the role and significance of the cultural factor in various interactions between parts of divided cities on the importance of such elements as: degree of social (civil) activity, sociocultural activity, ethnic, language, and religious distance. The subject of building social memory as a factor that most often hinders trans-border relations has not attracted much attention yet. This offers a unique opportunity to initiate such research based on the methodological proposal presented in this text, whose usefulness will be verified by in-depth case studies.

\section{References:}

Assmann, A. (2009). Pięć strategii wypierania ze świadomości. In: M. Saryusz-Wolska (Ed.). Pamięć zbiorowa i kulturowa. Wspótczesna perspektywa niemiecka (pp. 333-348). Kraków: Universitas.

Barszcz, A., \& Pilawa, K. (2018). Polityka historyczna. Próba programu pozytywnego. Pressje, 53, 49-59.

Burghardt, A.F. (1971). A Hypothesis about Gateway Cities. Annals of the Association of American Geographers, 61(2), 269-285. DOI: 10.1111/j.1467-8306.1971.tb00782.x. Buursink, J. (2001). The Binational Reality of Border-Crossing Cities. GeoJournal, 54, 7-19. DOI: 10.1023/A:1021180329607.

Chrobaczyński, J. (2018). Jak polityka historyczna ustanawia, filtruje i usuwa bohaterów. In: A. Bartuś (Ed.). Bohaterowie i antybohaterowie wspótczesnej Europy (pp. 97-112). Oświęcim: Urząd Miasta Oświęcim.

Chwedoruk, R. (2018). Polityka historyczna. Warszawa: PWN.

Dębicki, M., \& Tamáska, M. (2014). Laboratories of Integration: Divided Twin Towns at River Borders in the Visegrad Countries and Germany. socio.hu: Social Science Review, Special Issue 2: Sociological Aspects of Central Europe, 1-20. DOI: 10.18030/socio.hu.2014en.1.

Harvey, D.Ch. (2012). Review of the book Divided Cities: Belfast, Beirut, Jerusalem, Mostar, and Nicosia, by Jon Calame and Esther Charlesworth. Societies Without Borders, 7(3), 380-384.

Joenniemi, P., \& Sergunin, A. (2009). When Two Aspire to Become One: City-Twinning in Northern Europe. DIIS Working Paper, 21, 1-40.

Kansteiner, W. (2002). Finding Meaning in Memory: A Methodological Critique of Collective Memory Studies. History and Theory, 41(2), 179-197. DOI: 10.1111/00182656.00198.

Kącka, K. (2015a). Polityka historyczna: kreatorzy, narzędzia, mechanizmy działania przykład Polski. In: K. Kącka, J. Piechowiak-Lamparska, A. Ratke-Majewska (Eds.). Narracje pamięci: między polityka a historia (pp. 59-80). Toruń: Wydawnictwo Naukowe UMK. 
Kącka, K. (2015b). Społeczeństwo wobec kultury i dziedzictwa kulturowego. Polsko-niemieckie inicjatywy kulturalne i ich rola w kształtowaniu pamięci. In: K. Ziemer (Ed.). Pamięć i polityka wobec dziedzictwa kulturowego w Polsce i w Niemczech (pp. 44-67). Warszawa: Uniwersytet Kardynała Stefana Wyszyńskiego.

Kęsik, G. (2015). Polityka wobec miejskich przestrzeni historycznych w Polsce i w Niemczech. In: K. Ziemer (Ed.). Pamięć i polityka wobec dziedzictwa kulturowego w Polsce i w Niemczech (pp. 94-116). Warszawa: Uniwersytet Kardynała Stefana Wyszyńskiego.

Koselleck, R. (2006). Der 8. Mai zwischen Erinnerung und Geschichte. In: R. von Thadden, \& S. Kaudelka (Eds.). Erinnerung und Geschichte: 60 Jahre nach dem 8. Mai 1945 (pp. 13-24). Göttingen: Wallstein Verlag.

Kostro, R. (2009). Polityka, historia, propaganda. In: P. Skibiński, \& T. Wiścicki (Eds.). Polityka czy propaganda. PRL wobec historii (pp. 7-12). Warszawa: Muzeum Historii Polski.

MacDonald, D.B. (2005). Serbia and the Jewish Trope: Nationalism, Victimhood and the Successor Wars in Yugoslavia. In: W. Burszta, T. Kamusella, \& S. Wojciechowski (Eds.). Nationalisms across the Globe: An Overview of Nationalisms in State-Endowed and Stateless Nations.Vol. 1: Europe (pp. 97-127). Poznań: Wyższa Szkoła Nauk Humanistycznych i Dziennikarstwa.

Malczewska-Pawelec, D., \& Pawelec, T. (2011). Rewolucja w pamięci historycznej. Porównawcze studia nad praktykami manipulacji zbiorowa pamięcią Polaków w czasach stalinowskich. Kraków: Universitas.

Meier, Ch. (1987). Eröffnungsrede zur 36. Versammlung deutsche Historiker in Trier, 8 Oktober 1986. In: R. Augstein, K.D. Bracher, M. Broszat, J. Habermas, \& J.C. Fest (Eds.). „Historikerstreit”. Die Dokumentation der Kontroverse um die Einzigartigkeit der nationalsozialistischen Judenvernichtung (pp. 204-214). München: Piper.

Nijakowski, L. (2006). Domeny symboliczne. Konflikty narodowe $i$ etniczne $w$ wymiarze symbolicznym. Warszawa: SCHOLAR.

Nijakowski, L. (2008). Polska polityka pamięci. Esej socjologiczny. Warszawa: WAiP.

Olędzka, J. (2017). Konflikty pamięci a geopolityka przestrzeni poradzieckiej. In: E. Dąbrowicz, B. Larenta, \& M. Domurad (Eds.). Świadectwa pamięci. W kręgu źródet i dyskursów (od XIX wieku do dzisiaj) (pp. 337-345). Białystok: Alter Studio.

Ponczek, E. (2013). Polityka wobec pamięci versus polityka historyczna: aspekty semantyczny, aksjologiczny i merytoryczny w narracji polskiej. Przeglad Politologiczny, 2, 7-22. DOI: $10.14746 /$ pp.2013.18.2.1.

Rosenfeld, G.D. (2009). A Looming Crash or a Soft Landing? Forecasting the Future of the Memory "Industry". The Journal of Modern History, 81(1), 122-158. DOI: $10.1086 / 593157$.

Schultz, H., Stokłosa, K., Jajeśniak-Quast, D. (2002). Twin Towns on the Border as Laboratories of European Integration. F.I.T. Discussion Paper, 4, 1-75.

Skoczylas, Ł. (2015). Lokalne polityki pamięci. Środkowoeuropejskie Studia Polityczne, 4, 247-261. DOI: 10.14746/ssp.2015.4.15.

Ugrešić, D. (2006). Kultura ktamstwa (eseje antypolityczne). Wołowiec: Wydawnictwo Czarne. 
Wałdoch, M. (2017). Meandry polityki historycznej w jednostkach samorządu terytorialnego III RP. Studia Gdańskie. Wizje i rzeczywistość, 14, 49-67.

Wolff-Powęska, A. (2007). Polskie spory o historię i pamięć. Polityka historyczna. Przeglad Zachodni, 63(1), 3-44.

Wolff-Powęska, A. (2010). Miasto w poszukiwaniu nowej kultury pamięci. Poznań z Wrocławiem i Szczecinem w tle. In: W. Łazuga, \& S. Paczos (Eds.). Poznań, Szczecin, Wrocław. Trzy uniwersytety, trzy miasta, trzy regiony (pp. 53-70). Kraków-Poznań: Wydawnictwo Libron - Filip Lohner, Instytut Historii Uniwersytetu im. Adama Mickiewicza.

Woźniak, M., \& Napora, M. (2018). Przeszłość/historia w dyskursach publicznych. Wprowadzenie. Historyka. Studia Metodologiczne, 48, 215-219. DOI: 10.24425/ hsm.2018.124617.

Wójcik, A. (2016). Polityka historyczna jako forma budowy wizerunku Polski na arenie międzynarodowej. Świat Idei i Polityki, 15, 438-451.

Zenderowski, R. (2009). Wyścig wiktymistyczny w Europie Środkowo-Wschodniej. O wyższości Holocaustu nad Golden Age. Studia Bobolanum, 3, 65-93.

Zenderowski, R., \& Brzezińska, M. (2014). Miasta podzielone granicą państwową w nowych państwach członkowskich UE: od separacji do integracji. Pogranicze. Polish Borderlands Studies, 2(2), 164-183.

Zinn, H. (1970). The Politics of History. Urbana: University of Illinois Press. 